\title{
Combination of Gamma Irradiation and Sodium Carbonate Pretreatment on Oil Palm Empty Fruit Bunch (EFB) for High Acidic Hydrolysis Yield \\ (Gabungan Prarawatan Iradiasi Gamma dan Natrium Karbonat ke atas Serabut Tandan Kosong Kelapa Sawit (EFB) untuk Hasil Hidrolisis Asid Tinggi)
}

\author{
Siew Xian Chin* Chin Hua Chia, SARAni ZaKaria, SAHrim Hu. AhMAD \& Siti MaSrinda TASIRIN
}

\begin{abstract}
Oil palm empty fruit bunch ( $\mathrm{EFB}$ ) fibres were pretreated by gamma irradiation followed by sodium carbonate $\left(\mathrm{Na}_{2} \mathrm{CO}_{3}\right)$ before the acid hydrolysis process to produce reducing sugars using diluted sulphuric acid $\left(\mathrm{H}_{2} \mathrm{SO}_{4}\right)$. In this study, EFB fibres were irradiated at different doses, i.e. 0, 100 and $200 \mathrm{kGy}$. Meanwhile, the gamma irradiated sample were then subjected to $\mathrm{Na}_{2} \mathrm{CO}_{3}$ pretreatment with $\mathrm{O}$ and $5 \%$ total titratable alkali (TTA). The effect of the pretreatment using gamma irradiation and $\mathrm{Na}_{2} \mathrm{CO}_{3}$ on the physical and chemical properties of the EFB fibres and the yield of the reducing sugar obtained from the acid hydrolysis process was investigated. The obtained results showed that the content of holocellulose was increased significantly with the increase of irradiation doses combined with $\mathrm{Na}_{2} \mathrm{CO}_{3}$ pretreatment, whereas lignin content of the EFB was decreased. The gamma irradiation and $\mathrm{Na}_{2} \mathrm{CO}_{3}$ pretreatment resulted in structure breakage and removal of silica of EFB fibres which can be due to the swelling of the fibres. A synergistic effect between gamma irradiation and $\mathrm{Na}_{2} \mathrm{CO}_{3}$ was observed, in which the yield of reducing sugars was increased by combining the gamma irradiation and $\mathrm{Na}_{2} \mathrm{CO}_{3}$ pretreatment.
\end{abstract}

Keywords: Acid hydrolysis; holocellulose; lignin; sodium carbonate

\section{ABSTRAK}

Serabut tandan kosong kelapa sawit ( $\mathrm{EFB}$ ) telah diprarawat dengan iradiasi gamma dan natrium karbonat $\left(\mathrm{Na}_{2} \mathrm{CO}_{3}\right)$ sebelum proses hidrolisis asid untuk penghasilan gula penurun menggunakan asid sulfurik cair $\left(\mathrm{H}_{2} \mathrm{SO}_{4}\right)$. Dalam kajian ini, EFB diradiasikan pada dos sinaran gamma yang berbeza iaitu, 0, 100 dan 200 kGy. Kemudian, EFB tersebut diprarawat dengan $\mathrm{Na}_{2} \mathrm{CO}_{3}$ pada kepekatan $\mathrm{O}$ dan $5 \%$ kealkalian boleh titrat (TTA). Kesan prarawatan iradiasi gamma dan $\mathrm{Na}_{2} \mathrm{CO}_{3}$ terhadap sifat fizikal dan kimia EFB serta penghasilan gula penurun daripada proses hidrolisis asid telah dikaji. Keputusan yang diperoleh menunjukkan kesan prarawatan menyebabkan peningkatan kandungan holoselulosa yang ketara dengan peningkatan dos iradiasi gamma digabungkan dengan prarawatan $\mathrm{Na}_{2} \mathrm{CO}_{3}$, manakala kandungan lignin daripada EFB semakin berkurang. Prarawatan iradiasi gamma dan $\mathrm{Na}_{2} \mathrm{CO}_{3}$ boleh menyebabkan kerosakan struktur dan penyingkiran silika daripada gentian EFB disebabkan oleh kesan pembengkakan gentian. Kesan sinergistik antara iradiasi gamma dan $\mathrm{Na}_{2} \mathrm{CO}_{3}$ diperhatikan, dengan penghasilan gula penurun meningkat kesan gabungan prarawatan iradiasi gamma dan $\mathrm{Na}_{2} \mathrm{CO}_{3}$.

Kata kunci: Hidrolisis asid; holoselulosa; lignin; natrium karbonat

\section{INTRODUCTION}

In recent decade, the depletion of global fossil oil resources and the exploration for the renewable resources has been among the hottest topics of the world. Efforts have been made to search for alternative sources of energy (Folkedahl et al. 2011). Forest and agricultural by-product have become potential candidates for alternative energy source. Lignocellulosic materials can be converted into fuels and chemicals, which can be used for the production of various type of industrial and non-food consumer products, such as chemical and polymeric materials (Guo et al. 2012).

In Malaysia, lignocellulosic biomass can be obtained easily and it can be a potential alternative resource of renewable energy production (Shamsudin et al. 2012; Shuit et al. 2009). Oil palm EFB has several characteristics that make it a potential raw material, including high holocellulose content, widely available and low cost (Ibrahim et al. 2012; Omar et al. 2011; Zakaria et al. 2014).

Pretreatment is an important process in enhancing enzymatic or acid hydrolysis of lignocellulosic material (Goshadrou et al. 2011). It has been proven as one of the effective ways in the bioconversion of lignocellulosic material into various chemical feedstocks. In general, there are three types of pretreatment processes, i.e. physical, chemical and physical-chemical (Binod et al. 2010). It is well known that the presence of lignin in the lignocellulosic biomass will detrimentally affect the conversion yield of the process by inhibiting the reaction between the chemicals and polysaccharides due to its recalcitrant nature (Chaudhary et al. 2012; Chen et al. 2007; Newman et al. 
2013; Xu et al. 2010). Therefore, one of the main targets of pretreatments is to remove lignin.

It has been proven that radiation pretreatment can increase sugars yield for various lignocellulosic materials, such as bagasse (Han et al. 1981), wheat straw (Yang et al. 2008), and marine algae (Yoon et al. 2012). Gamma irradiation can cause degradation of the chemical links between lignin, hemicellulose and cellulose (Chaudhary et al. 2012). Meanwhile, alkaline pretreatment on lignocellulose materials have received increasing attention due to many advantages, including relatively cheap, good efficiency towards delignification, disruption of structural linkages of lignocellulosic, decrystallization of cellulose, depolymerization of the carbohydrates and change of compositions through alkali swelling (Carrillo et al. 2005; Chaudhary et al. 2012; Yang et al. 2012). Besides, to further maximize the yield of reducing sugars, combination of pretreatment methods, such as gamma irradiation and alkaline treatment, has been proposed to reduce the required irradiation dose cost of the pretreatment (Kumakura \& Kaetsu 1984).

The objectives of the present work were to investigate the effects of gamma irradiation followed by alkaline pretreatment using sodium carbonate on the physical and chemical properties of the oil palm EFB fibres. The pretreated EFB fibres were then hydrolyzed into reducing sugars by acid hydrolysis using low acid concentration. This investigation would provide further understanding on the application and fundamental of gamma irradiation and alkaline pretreatment to maximize the production of reducing sugar from oil palm EFB fibres.

\section{MATERIALS AND METHODS}

Oil Palm EFB fibres were purchased from Szetech Engineering Sdn. Bhd. Oil palm EFB fibres were sieved into size range from 150 to $500 \mu \mathrm{m}$. Analytical grade chemicals, sodium hydroxide, $\mathrm{NaOH}$ (purity ${ }^{3} 99 \%$ ), sulfuric acid, $\mathrm{H}_{2} \mathrm{SO}_{4}$ (purity 95-98\%) and glacial acetic acid, $\mathrm{CH}_{3} \mathrm{COOH}$ were purchased from Merck (Darmstadt, Germany). Sodium chlorite, $\mathrm{NaClO}_{2}$ (purity ${ }^{380 \%}$ ) was purchased from Acros Organic (Geel, Belgium). Sodium carbonate, $\mathrm{Na}_{2} \mathrm{CO}_{3}$ (purity ${ }^{3}$ 99.5\%), 3, 5-Dinitrosalicyclic acid, 3, 5-DNS and potassium sodium tartrate, $\mathrm{KNaC}_{4} \mathrm{H}_{4} \mathrm{O}_{6} \cdot 4 \mathrm{H}_{2} \mathrm{O}$ (ACS Reagent) were purchased from Sigma Aldrich (Shanghai, China).

\section{GAMMA IRRADIATION AND SODIUM CARBONATE PRETREATMENT}

The EFB fibres were irradiated in a cobalt-60 irradiator (Gamma Cell GC 220 Excel) with $2.250 \mathrm{kGy} / \mathrm{h}$. The irradiated doses were 0,100 and $200 \mathrm{kGy}$, respectively. After that, the gamma irradiated EFB fibres were further treated with $\mathrm{Na}_{2} \mathrm{CO}_{3}$ at $150^{\circ} \mathrm{C}$ for $2 \mathrm{~h}$ using a $60 \mathrm{~mL}$ capacity autoclave in an oil bath. The total titratable alkali (TTA) of the pretreatment is based on the concentration of
$\mathrm{Na}_{2} \mathrm{O}$. In this study, two different TTA $\%$ were selected, i.e. 0 and $5 \%$, for the pretreatment of EFB fibres. The pretreated EFB fibres were washed with excess distilled water until $\mathrm{pH}$ neutral and dried in an oven at $105^{\circ} \mathrm{C}$ for $24 \mathrm{~h}$. EFB fibres were stored in a desiccator for further used. Meanwhile, moisture content of EFB fibres was measured using a moisture analyzer (AND MX-50).

\section{LIGNIN AND HOLOCELLULOSE CONTENT DETERMINATION}

Lignin content of the EFB fibres was determined according to TAPPI T-222 om-83. Briefly, EFB fibres were hydrolysed and solubilized by $\mathrm{H}_{2} \mathrm{SO}_{4}$. The acid-insoluble lignin was filtered off, dried and weighed. In this method, lignin is defined as wood or pulp constituent insoluble in $72 \%$ sulphuric acid (Piarpuzán 2011). The holocellulose fraction was determined according to the Wise and Murphy (1946) method using acetic acid and sodium chlorite at $80^{\circ} \mathrm{C}$ for $1 \mathrm{~h}$. This step was repeated for three times and cooled in an ice bath, filtered with iced distilled water and washed with acetone. The product was then dried and weighed for the calculation of holocellulose content.

\section{CHARACTERIZATION}

\section{X-RAY DIFFRACTION (XRD)}

Powder X-ray diffraction of the raw and pretreated EFB fibres was carried out using an X-ray diffractometer (Bruker AXS D8 Advance). The sample was scanned at a range of $5-60^{\circ}$. The degree of crystallinity $(\mathrm{CrI} \%)$ of the EFB samples was determined using Segal's equation as follow:

$$
C r I \%=\left[I_{002}-I_{A M} / I_{002}\right] \times 100 \%
$$

\section{SCANNING ELECTRON MICROSCOPE (SEM)}

Surface morphology of the raw and pretreated EFB fibres was observed using a scanning electron microscope (SEM - Philips XL-30).

\section{ACID HYDROLYSIS OF EFB FIBRES}

Acid hydrolysis of the EFB fibres was carried out in a 60 $\mathrm{mL}$ capacity high pressure stainless steel autoclave with Teflon-lined at $150^{\circ} \mathrm{C}$ in an oil bath using $0.25 \mathrm{~N} \mathrm{H}_{2} \mathrm{SO}_{4}$ at reaction time $(20,40 \& 60 \mathrm{~min})$. After the hydrolysis reaction, the autoclave was quickly immersed into an ice water bath to stop the reaction. The hydrolysate was centrifuged at $12000 \mathrm{rpm}$ for $10 \mathrm{~min}$ to separate the solid and liquid phases. The obtained solution was then neutralised with $0.25 \mathrm{~N} \mathrm{NaOH}$ solution. The total reducing sugar (TRS) in the hydrolysate was determined using the 3 , 5-dinitrosalicyclic acid (DNS) according to Miller's method (Miller 1959). An acid hydrolysis of untreated EFB fibres was conducted as the control experiment. 


\section{RESULTS AND DISCUSSION}

Effect of pretreatment on the solid yield, holocellulose and lignin of pretreated EFB fibres

The effect of the pretreatment on the total solid yield of EFB fibres is shown in Table 1. The solid yield is important in indicating the effectiveness of lignin removing process during pretreatment. As can be seen, the gamma irradiated EFB fibres $(0,100,200 \mathrm{kGy})$ followed by 0 and $5 \%$ TTA pretreatment showed a similar trend of reduction in solid yield. The higher irradiation doses combined with the increased of TTA\%, the lower the solid yields. This is due to the greater degradation of lignin and some carbohydrates of the EFB fibres at higher gamma irradiation doses and higher alkaline condition (Yang et al. 2013).

The proximate compositions (holocellulose and lignin) of the raw and pretreated EFB fibres are shown in Table 1. The holocellulose content was used to calculate the total reducing sugar yield of the acid hydrolysis. As can be seen from Table 1, gamma irradiation pretreated samples gave approximately the same amount of holocellulose and lignin content. However, with the $\mathrm{Na}_{2} \mathrm{CO}_{3}$ pretreatment, the holocellulose content increased while the lignin content decreased. This is attributed by the removal of lignin via alkaline pretreatment. The same phenomena can be observed from our previous study, as the concentration of $\mathrm{Na}_{2} \mathrm{CO}_{3}$ increases, the holocellulose content increases (Chin et al. 2014).

Further pretreatment on the irradiated EFB fibres shows increased of holocellulose content due to the destruction of the chemicals linkage between cellulose, hemicellulose and lignin of the fibres after gamma irradiation pretreatment (Wang et al. 2012). Alkaline pretreatment (5\% TTA) on $200 \mathrm{kGy}$ irradiated EFB fibres gave the lowest solid yield and highest holocellulose content as compared to the fibres irradiated with 100 $\mathrm{kGy}$ and pretreated with 5\% TTA. This is because higher irradiation dose of gamma irradiation would disrupt the polysaccharides chain and increase the reactive area for the reaction with $\mathrm{Na}_{2} \mathrm{CO}_{3}$, promoting degradation of polysaccharides, especially hemicelluloses (xylan) and amorphous cellulose (Yang et al. 2012).
EFFECT OF PRETREATMENT ON THE DEGREE OF CRYSTALLINITY OF PRETREATED EFB FIBRES

The degree of crystallinity (CrI\%) of the EFB samples are shown in Table 2. The CrI\% of the gamma irradiation pretreated EFB fibres $(0,100,200 \mathrm{kGy})$ reduced slightly after exposure to gamma irradiation ranging from 57.99 to $55.74 \%$. No remarkably change can be observed. However, the $\mathrm{CrI} \%$ of gamma irradiation pretreated $\mathrm{EFB}$ fibres were increased after further pretreated with $\mathrm{Na}_{2} \mathrm{CO}_{3}$ from $0 \%$ and $5 \%$ TTA. This might be due to the removal of hemicelluloses and amorphous region of cellulose in the fibres after alkaline pretreatment. This can be correlated with the holocellulose and lignin content as shown in Table 1, in which alkaline pretreatment tends to remove lignin and thus increase holocellulose content of EFB fibres (Chung et al. 2012).

The samples pretreated with the same TTA\% but combined with increasing of gamma irradiation doses show a reduction of $\mathrm{CrI} \%$. This result can be explained by the fact that combined pretreatment has a substantial synergistic effect on the CrI\% compared to each pretreatment. In which, higher dose of gamma irradiation causing more disruption on EFB fibres thus increase the accessibility of EFB fibres. Therefore, this enhanced the effectiveness of $\mathrm{Na}_{2} \mathrm{CO}_{3}$ in removing the lignin content in EFB fibres. In general, gamma irradiation on lignocellulosic material causes depolymerisation of biopolymers and decomposition of carbohydrates thus resulting reduction in crystallinity and thus increases the ability in digestibility (Han et al. 1981).

\section{EFFECT OF PRETREATMENT ON THE MORPHOLOGY OF PRETREATED EFB FIBRES (SEM)}

Figure 1 shows the morphology of the raw EFB fibre and pretreated EFB fibres. As can be clearly seen in Figure 1(a), originally the surface of the fibres was rigid and smooth with the presence of many phytoliths with embedded silica particles. This formed a protective layer for the fibres against any biodegradation or chemical attacks (Hong et al. 2013; Kim et al. 2008). Hence, EFB fibres are an inferior feedstock for reducing sugar production due to its high ash, silica and lignin content.

TABLE 1. Solid yield and compositions of raw and pretreated EFB fibres

\begin{tabular}{lccc}
\hline EFB fibres & Solid yield & Holocellulose (wt. \%) & Klason lignin (wt. \%) \\
\hline $0 \mathrm{kGy}$ & $100 \%$ & $67.19 \%$ & $24.92 \%$ \\
$0 \mathrm{kGy}(0 \%$ TTA) & $76.02 \%$ & $68.10 \%$ & $21.18 \%$ \\
$0 \mathrm{kGy}(5 \%$ TTA) & $70.78 \%$ & $71.68 \%$ & $20.33 \%$ \\
$100 \mathrm{kGy}$ & $99.30 \%$ & $66.15 \%$ & $24.76 \%$ \\
$100 \mathrm{kGy}(0 \%$ TTA) & $65.24 \%$ & $69.81 \%$ & $21.76 \%$ \\
$100 \mathrm{kGy}(5 \%$ TTA) & $59.62 \%$ & $72.48 \%$ & $19.02 \%$ \\
$200 \mathrm{kGy}$ & $98.24 \%$ & $66.67 \%$ & $25.83 \%$ \\
$200 \mathrm{kGy}(0 \%$ TTA) & $60.90 \%$ & $70.45 \%$ & $20.89 \%$ \\
$200 \mathrm{kGy}(5 \%$ TTA) & $49.52 \%$ & $72.66 \%$ & $18.07 \%$ \\
\hline
\end{tabular}


TABLE 2. Degree of crystallinity of raw and pretreated EFB fibres

\begin{tabular}{lc}
\hline EFB fibres & CrI (\%) \\
\hline 0 kGy & 58.0 \\
0 kGy 0\% & 65.3 \\
0 kGy 5\% & 66.6 \\
100 kGy & 55.9 \\
100 kGy 0\% & 65.1 \\
100 kGy 5\% & 62.1 \\
200 kGy & 55.6 \\
200 kGy 0\% & 65.9 \\
\hline 00 kGy 5\% & 62.0 \\
\hline
\end{tabular}

Figure 1(b) shows the morphology of $200 \mathrm{kGy}$ irradiated EFB fibres. The surface becomes rougher as compared with the untreated EFB fibres. The surface is uneven with some empty cavities and minor separation of the cell wall can be observed. This was due to structural changes caused by the gamma irradiation (Alemdar \& Sain 2008). In general, gamma irradiation of lignocellulosic materials causes depolymerization of biopolymers and decomposition of carbohydrates and the resulting material shows a loss in crystallinity. Hence, the increase of accessible surface area could increase the accessibility of acid during hydrolysis process (Han et al. 1981; Wang et al. 2012).

Figure 1(c) shows the surface morphology of $0 \mathrm{kGy}$ (0\% TTA) EFB fibres. The surface of the fibre became rougher after the autohydrolysis pretreatment using water due to the removal of impurities and wax. The presence of silica on the surface of EFB fibres can be clearly seen after the autohydrolysis process. Meanwhile Figure 1(d) shows the surface of $200 \mathrm{kGy}(0 \%$ TTA) EFB fibres. The surface is rougher with some empty cavities and some silica can be seen. This was due to the disruption structure of EFB fibre by gamma irradiation thus increase the accessibility of water towards the fibres (Wang et al. 2012).

Figure 1(e) shows the micrograph of $0 \mathrm{kGy}$ (5\% TTA) EFB fibre. Meanwhile, Figure 1(f) shows the micrograph of $200 \mathrm{kGy}$ (5\% TTA) EFB fibre. Remarkable different can be seen from this image where the surface of Figure 1(e) is smoother as compare with Figure 1(f). The surface of $200 \mathrm{kGy}$ (5\% TTA) EFB fibre is more porous. Silica particles were removed, leaving obvious empty craters on the surface as compared to Figure 1(e). It also showed that after pretreatment, the rigidness of EFB fibres can be reduced to show existence of macrofibrils which can result in increase on the specific surface area (Kim et al. 2008; Sun et al. 2013).

\section{EFFECT OF PRETREATMENT ON ACID HYDROLYSIS OF EFB FIBRES}

The effects of gamma irradiation and $\mathrm{Na}_{2} \mathrm{CO}_{3}$ pretreatment on the hydrolysis of EFB fibres to produce reducing sugar from EFB fibres were studied at $150^{\circ} \mathrm{C}$ using $0.25 \mathrm{~N} \mathrm{H}_{2} \mathrm{SO}_{4}$ at reaction times $(20,40 \& 60 \mathrm{~min})$. This experimental condition was chosen based on the previous preliminary study which is not shown in this work.

Figure 2(a) shows the reducing sugar yield obtained from the acid hydrolysis of the EFB fibres after irradiated at doses 0, 100 and $200 \mathrm{kGy}$. In general, raw EFB fibres (0 $\mathrm{kGy}$ ) gave the lowest reducing sugar yield at every reaction time. This can be due to the high lignin content and rigid structure of the fibre, retarding the hydrolysis reaction (Chin et al. 2013). $200 \mathrm{kGy}$ irradiated EFB fibres provided the highest reducing sugars yield, i.e. $60.35 \%$ at reaction time of $20 \mathrm{~min}$. This is because gamma irradiation can cause
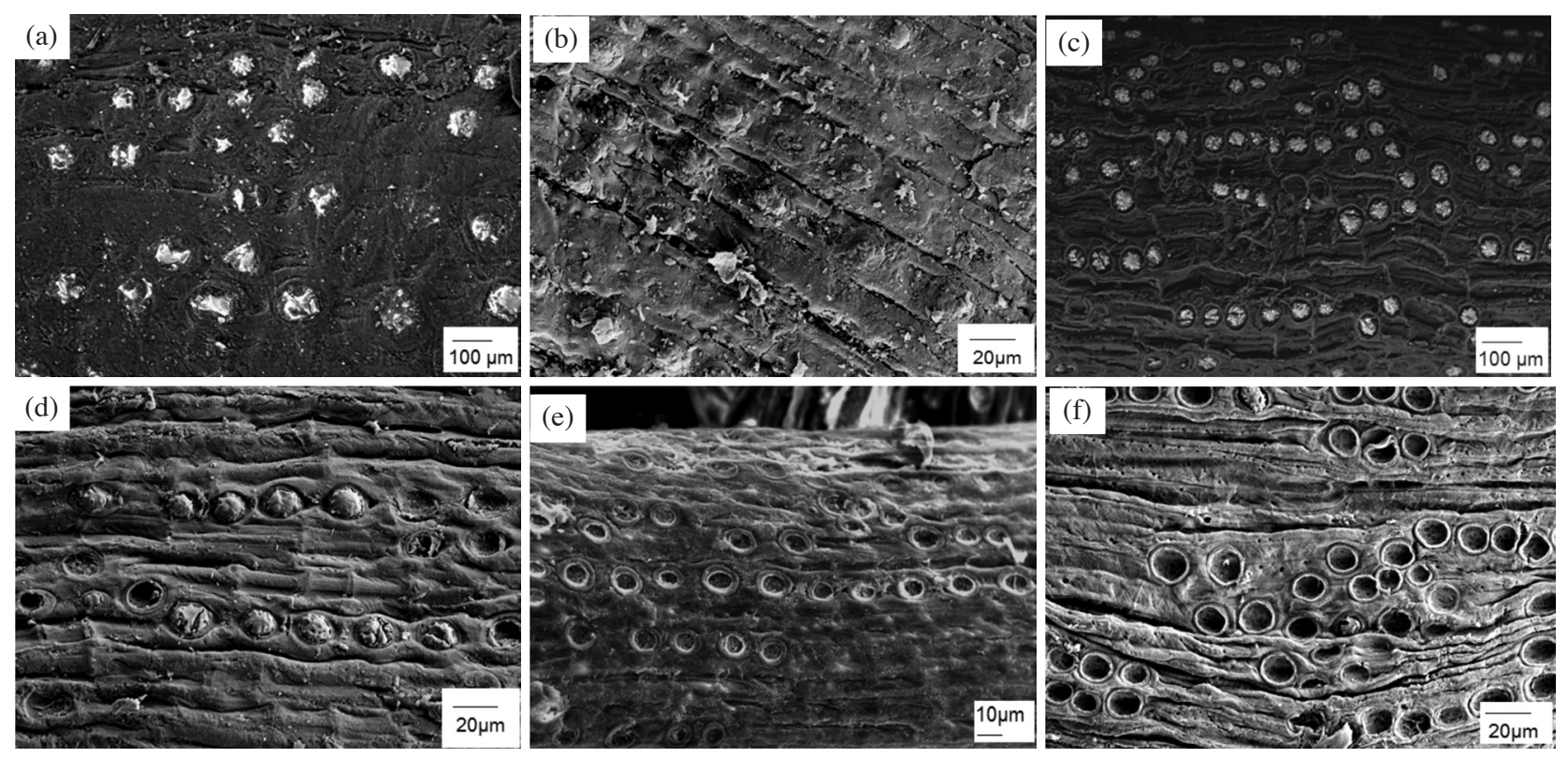

FIGURE 1. SEM micrographs of (a) raw EFB fibres, 0 kGy (b) 200 kGy (c) 0 kGy (0\% TTA) (d) 200 kGy (0\% TTA)

(e) $0 \mathrm{kGy}(5 \%$ TTA) (f) $200 \mathrm{kGy}(5 \%$ TTA) 
cleavage of hemicelluloses and cellulose, thus increasing the accessibility of acid during hydrolysis (Ribeiro et al. 2013).

Figure 2(b) shows the reducing sugar yield of the EFB fibres irradiated with gamma irradiation followed by $0 \%$ TTA pretreatment. As compared with Figure 2(a) and 2(c), the overall yield of reducing sugar is the lowest showing that $0 \%$ TTA will enhance autohydrolysis effect where most of the hemicelluloses will be degraded after the pretreatment.

Figure 2(c) shows the reducing sugar yield of gamma irradiation pretreated EFB fibres followed by 5\% TTA pretreatment. Maximum reducing sugar yield $(65.03 \%)$ was achieved by $200 \mathrm{kGy}, 5 \%$ TTA pretreated EFB fibres at $60 \mathrm{~min}$. As compared with Figure 2(a), at the reaction time of $20 \mathrm{~min}$, the yield of reducing sugar of combined pretreated EFB fibres was lower than gamma irradiation pretreated EFB fibres. This is because alkaline pretreatment can remove lignin from the fibres. However, some of the hemicelluloses and amorphous cellulose will also be degraded (Yang et al. 2012), which made the fibres more difficult to be hydrolysed. Hemicellulose is more easily to be hydrolysed as compared with cellulose due to its heterogeneous structure and lower degree of polymerization (Hong et al. 2013; Zaldivar et al. 2001).
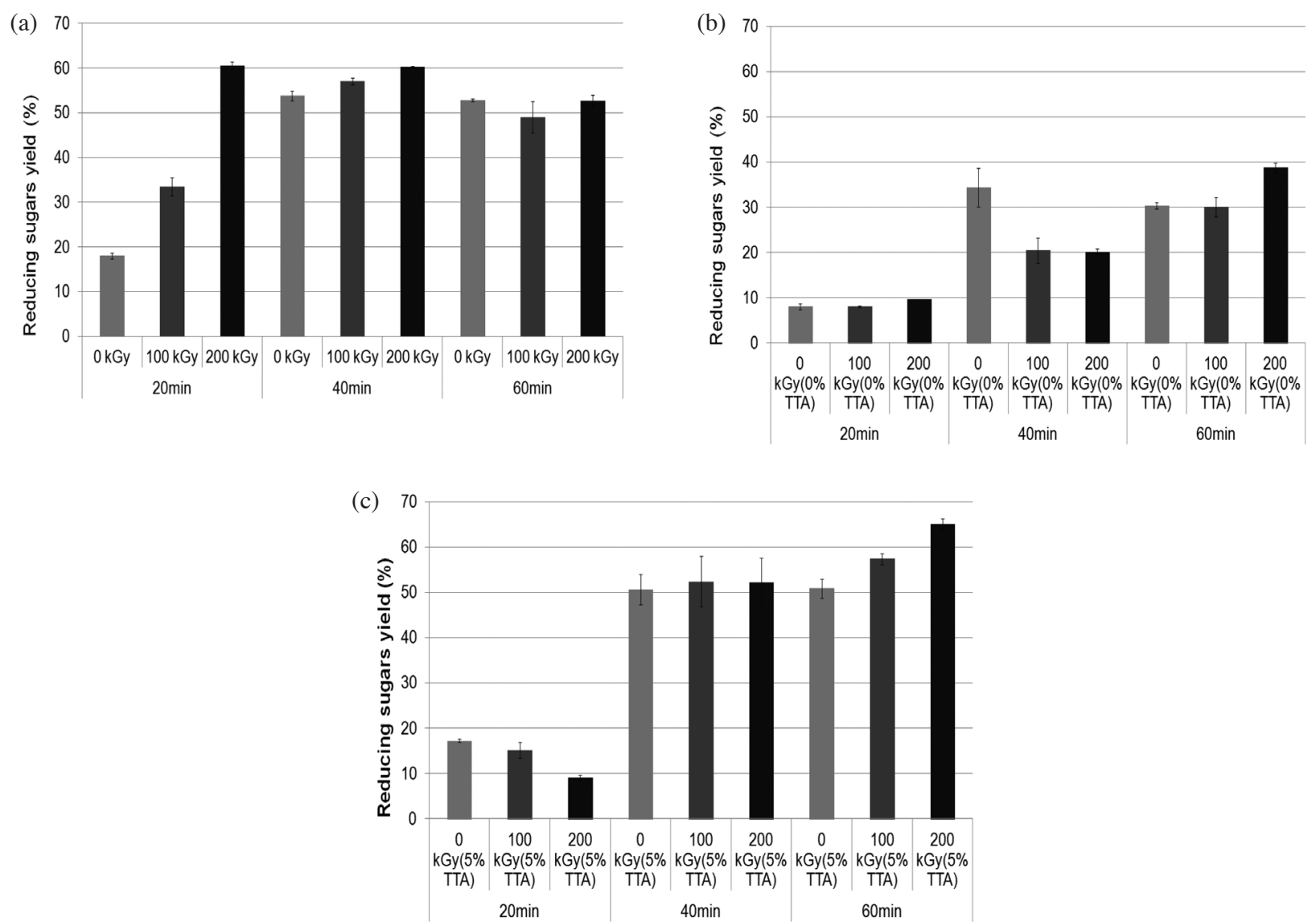

FIGURE 2. Reducing sugar yield obtained by $0.25 \mathrm{~N} \mathrm{H}_{2} \mathrm{SO}_{4}$ acid hydrolysis of pretreated EFB fibres: (a) $0 \mathrm{kGy}, 100 \mathrm{kGy}$ and 200 kGy irradiated EFB fibres (b) $0 \mathrm{kGy}, 100 \mathrm{kGy}$ and $200 \mathrm{kGy}$ irradiated EFB fibres following by $0 \%$ TTA pretreatment

(c) $0 \mathrm{kGy}, 100 \mathrm{kGy}$ and $200 \mathrm{kGy}$ irradiated EFB fibres following by 5\% TTA pretreatment
From Figure 2(a)-2(c), the overall release of sugar was increased with the combination pretreatment of $\mathrm{Na}_{2} \mathrm{CO}_{3}$. For EFB fibres that were only irradiated with gamma irradiation without alkaline treatment, the reducing sugar mainly due to xylose while later combine pretreatment is mainly from cellulose (Hong et al. 2013). After the pretreatment combination, the relative content of glucose was significantly enhanced (Wang et al. 2012). This showed that after combined pretreatment, the holocellulose content mostly is cellulose rather than hemicelluloses. Gamma irradiation pretreatment obviously destroyed the fibers and increased the exposed surface area which is beneficial to enhance the hydrolysis process. In general, gamma irradiation of lignocellulosic material can cause depolymerization of the biopolymers, while mild alkaline treatment can lead to partial decomposition of carbohydrates, which will increase digestibility during hydrolysis (Chin et al. 2013). This result can be explained by the fact that by combining pretreatment using gamma irradiation and alkaline treatment, a substantial synergistic effect can be observed on the acid hydrolysis of the EFB fibres, as compared to each pretreatment. This is consistent with solid yield, holocellulose, lignin, XRD and SEM results. 


\section{CONCLUSION}

Based on current study, the best pretreatment conditions for EFB fibres were $200 \mathrm{kGy}$ combined with 5\% TTA under acid hydrolysis process for $60 \mathrm{~min}, 150^{\circ} \mathrm{C}$ and $0.25 \mathrm{~N} \mathrm{H}_{2} \mathrm{SO}_{4}$ give reducing sugar yield of $65.03 \%$. Gamma irradiation pretreatment and combined pretreatment showed a great influence on acid hydrolysis, resulted in the disruption of the link between hemicellulose, cellulose and lignin owing to cellulose crystallinity and morphology of the EFB fibres. Mild alkaline pretreatment can reduce the amount of lignin while preserving some hemicelluloses. This may concluded that combined pretreatment had a substantial synergistic effect on acid hydrolysis for by enhancing the yield of reducing sugars which make EFB fibres as a potential candidates in the production of bio-ethanol and other chemical feedstocks. This can also be conceived as the first step of gamma irradiation pretreatment by providing data that may be useful in the future development of gamma irradiation as one of the pretreatment method for lignocellulosic materials.

\section{REFERENCES}

Alemdar, A. \& Sain, M. 2008. Isolation and characterization of nanofibers from agricultural residues - Wheat straw and soy hulls. Bioresource Technology 99: 1664-1671.

Binod, P., Sindhu, R., Singhania, R.R., Vikram, S., Devi, L., Nagalakshmi, S., Kurien, N., Sukumaran, R.K. \& Pandey, A. 2010. Bioethanol production from rice straw: An overview. Bioresource Technology 101: 4767-4774.

Carrillo, F., Lis, M.J., Colom, X., López-Mesas, M. \& Valldeperas, J. 2005. Effect of alkali pretreatment on cellulase hydrolysis of wheat straw: Kinetic study. Process Biochemistry 40: 3360-3364.

Chaudhary, G., Singh, L.K. \& Ghosh, S. 2012. Alkaline pretreatment methods followed by acid hydrolysis of Saccharum spontaneum for bioethanol production. Bioresource Technology 124: 111-118.

Chen, Y., Sharma-Shivappa, R., Keshwani, D. \& Chen, C. 2007. Potential of agricultural residues and hay for bioethanol production. Applied Biochemistry and Biotechnology 142: 276-290.

Chin, S.X., Chia, C.H. \& Zakaria, S. 2014. Green liquor pretreatment of oil palm empty fruit bunch (EFB) fibres for high yield of reducing sugars. Journal of Biobased Materials and Bioenergy 8: 1-6.

Chin, S.X., Chia, C.H. \& Zakaria, S. 2013. Production of reducing sugar from oil palm empty fruit bunch (EFB) cellulose fibres via acid hydrolysis. BioResources 8: 447-460.

Chung, B.Y., Lee, J.T., Bai, H.W., Kim, U.J., Bae, H.J., GonWi, S. \& Cho, J.Y. 2012. Enhanced enzymatic hydrolysis of poplar bark by combined use of gamma ray and dilute acid for bioethanol production. Radiation Physics and Chemistry 81: 1003-1007.

Folkedahl, B.C., Snyder, A.C., Strege, J.R. \& Bjorgaard, S.J. 2011. Process development and demonstration of coal and biomass indirect liquefaction to synthetic iso-paraffinic kerosene. Fuel Processing Technology 92: 1939-1945.

Goshadrou, A., Karimi, K. \& Taherzadeh, M.J. 2011. Bioethanol production from sweet sorghum bagasse by Mucor hiemalis. Industrial Crops and Products 34: 1219-1225.
Guo, B., Zhang, Y., Ha, S.J., Jin, Y.S. \& Morgenroth, E. 2012. Combined biomimetic and inorganic acids hydrolysis of hemicellulose in Miscanthus for bioethanol production. Bioresource Technology 110: 278-287.

Han, Y.W., Timpa, J., Ciegler, A., Courtney, J., Curry, W.F. \& Lambremont, E.N. 1981. $\gamma$-ray-induced degradation of lignocellulosic materials. Biotechnology and Bioengineering 23: 2525-2535.

Hong, S.H., Lee, J.T., Lee, S.B., Wi, G.E., Cho, E.J., Singh, S., Lee, S.K. \& Chung, Y.B. 2013. Improved enzymatic hydrolysis of wheat straw by combined use of gamma ray and dilute acid for bioethanol production. Radiation Physics and Chemistry 94: 231-235.

Ibrahim, S.M., Badri, K.H. \& Hassan, O. 2012. A study on glycerolysis of oil palm empty fruit bunch fiber. Sains Malaysiana 41(12): 1579-1585.

Kim, T.H., Taylor, F. \& Hicks, K.B. 2008. Bioethanol production from barley hull using SAA (soaking in aqueous ammonia) pretreatment. Bioresource Technology 99: 5694-5702.

Kumakura, M. \& Kaetsu, I. 1984. Pretreatment by radiation and acids of chaff and its effect on enzymatic hydrolysis of cellulose. Agricultural Wastes 9: 279-287.

Miller, G.L. 1959. Use of dinitrosalicylicacid reagent for determination of reducing sugar Analytical Chemistry 31: 426-428.

Newman, R.H., Vaidya, A.A. \& Campion, S.H. 2013. A mathematical model for the inhibitory effects of lignin in enzymatic hydrolysis of lignocellulosics. Bioresource Technology 130: 757-762.

Omar, R., Idris, A., Yunus, R., Khalid, K. \& Aida-Isma, M.I. 2011. Characterization of empty fruit bunch for microwave-assisted pyrolysis. Fuel 90: 1536-1544.

Piarpuzán, D., Quintero, J.A. \& Cardona, C.A. 2011.Empty fruit bunches from oil palm as a potential raw material for fuel ethanol production. Biomass and Bioenergy 35: 1130-1137.

Ribeiro, M.A., Oikawa, H., Mori, M.N., Napolitano, C.M. \& Duarte, C.L. 2013. Degradation mechanism of polysaccharides on irradiated sugarcane bagasse. Radiation Physics and Chemistry 84: 115-118.

Shamsudin, S., Md Shah, U.K., Zainudin, H., Abd-Aziz, S., Mustapa Kamal, S.M., Shirai, Y. \& Hassan, M.A. 2012.Effect of steam pretreatment on oil palm empty fruit bunch for the production of sugars. Biomass and Bioenergy 36: 280-288.

Shuit, S.H., Tan, K.T., Lee, K.T. \& Kamaruddin, A.H. 2009. Oil palm biomass as a sustainable energy source: A Malaysian case study. Energy 34: 1225-1235.

Sun, J., Xu, L., Ge, M. \& Zhai, M. 2013. Radiation degradation of microcrystalline cellulose in solid status. Journal of Applied Polymer Science 127: 1630-1636.

Wang, K.Q., Xiong, X.Y., Chen, J.P., Chen, L., Su, X. \& Liu, Y. 2012. Comparison of gamma irradiation and steam explosion pretreatment for ethanol production from agricultural residues. Biomass and Bioenergy 46: 301-308.

Wise, L.E. \& Murphy, M.D.A.A.A. 1946. Chlorite holocellulose, its fractionation and bearing on summative wood analysis and on studies on the hemicelluloses. Paper Trade Journal 122: 11-19.

Xu, J., Cheng, J.J., Sharma-Shivappa, R.R. \& Burns, J.C. 2010. Lime pretreatment of switchgrass at mild temperatures for ethanol production. Bioresource Technology 101: 2900-2903.

Yang, C., Shen, Z., Yu, G. \& Wang, J. 2008. Effect and aftereffect of $\gamma$ radiation pretreatment on enzymatic hydrolysis of wheat straw. Bioresource Technology 99: 6240-6245. 
Yang, L., Cao, J., Mao, J. \& Jin, Y. 2013. Sodium carbonatesodium sulfite pretreatment for improving the enzymatic hydrolysis of rice straw. Industrial Crops and Products 43: 711-717.

Yang, L., Cao, J., Jin, Y., Chang, H.M., Jameel, H., Phillips, R. \& Li, Z. 2012. Effects of sodium carbonate pretreatment on the chemical compositions and enzymatic saccharification of rice straw. Bioresource Technology 124: 283-291.

Yoon, M., Choi, J.I., Lee, J.W. \& Park, D.H. 2012. Improvement of saccharification process for bioethanol production from Undaria sp. by gamma irradiation. Radiation Physics and Chemistry 81: 999-1002.

Zakaria, S., Roslan, R., Amran, U.A., Chia, C.H. \& Bakaruddin, S.B. 2014. Characterization of residue from EFB and kenaf core fibers in the liquefaction process. Sains Malaysiana 43(3): 429-435.

Zaldivar, J., Nielsen, J. \& Olsson, L. 2001. Fuel ethanol production from lignocellulose: A challenge for metabolic engineering and process integration. Applied Microbiology and Biotechnology 56: 17-34.
Siew Xian Chin* Chin Hua Chia, Sarani Zakaria \&

Sahrim Hj. Ahmad

Bioresources and Biorefinery Laboratory

School of Applied Physics, Faculty of Science and Technology

Universiti Kebangsaan Malaysia

43600 Bangi, Selangor Darul Ehsan

Malaysia

Siew Xian Chin* \& Siti Masrinda Tasirin

Department of Chemical and Process Engineering

Universiti Kebangsaan Malaysia

43600 Bangi, Selangor Darul Ehsan

Malaysia

*Corresponding author; email: sxchin88@hotmail.com

Received: 28 March 2015

Accepted: 26 January 2016 